Robert K. Stoelting MD, David P. Henry MD, Kenneth M. Verburg MD,

Richard L. McCammon MD, Robert D. King MD, John W. Brown MD

\title{
Haemodynamic changes and circulating histamine concentrations following protamine administration to patients and dogs
}

Hatmodynamic changes and the circulating concentra tions of histamine associated with the intravenous infusion of protamine were measured in six adult patients undergoing elective aortocaronary bypass grafi surgery and twelve halothane-anaesthetized dogs. Administrution of protamine $\left(4.7 \mathrm{mg} \cdot \mathrm{kg}^{-1}\right)$ aver five minutes to patients at the conclusion of cardiopulmonary bypass did not produce haemodynamic changes or alterations in the arterial ar mixed venous concentrations of histamine. Likewise, the administration of protamine $\left(4.5 \mathrm{mg} \cdot \mathrm{kg}^{-1}\right)$ over five minutes to six dogs produced no haemodynamic changes or alterations in the arterial concentrations of histamine. Conversely, administration of protamine $(4.5$ $m g \cdot \mathrm{kg}^{-1}$ ) as a rapid intravenous injection to six oiher dogs produced a decrease (about 30 per cent below cuntrol) in systolic, diastolic and mean arierial pressure ( $p<0.05$ ) at 2.5 minutes following the injection. These decreases in blood pressure were paralleled by increases

\section{Key words}

BLOOD, COAGULATION: protamine, cardiovascular effects of protamine, histamine.

From Indiana University School of Medicine and the Lilly Laboratory for Clinical Research, Indianapolis, Indiana.

Address correspondence to: Dr. Robert K. Stoelting. Department of Anesthesia, Fesler Hall Room 204, 1120 South Drive, Indiana University School of Medicine, Indianapolis, Indiana 46223. in the arterial concentration of histamine from $295 \pm 71$ pg-m $l^{-1}$ (mean $\pm S D$ ) before protamine $10860 \pm 6465$ $\mathrm{pg} \cdot \mathrm{m} \mathrm{l}^{-1}(p<0.05) 2.5$ minutes after protamine. Haemodynamic changes and the arterial concentation of hissamine were nor different from control file mumes after protamine administration.

It is consluded that administration of protanine over five minutes to patients or dogs does not evoke significant haemodynamic changes or alterations in circuiating concentrations of histamine. Conversely, rapid injection of proramine to dogs evokes transient decreases in blood pressure that are paralleled by increases in the atterial concentrations of histamine.

Haemodynamic changes evoked by the intravenous administration of protamine to reverse haparin anticoagulation may be species dependent. For example, studies in dogs describe hypotension, decreased systemic vascular resistance and bradycardia following the intravenous administration of protamine. ${ }^{1-3}$ In contrast, data obtained from patients suggests a more benign circulatory effect of protamine. ${ }^{4-6}$ When haemodynamic changes do accompany the adninistration of protamine, the transient decrease in blood pressure and the suggestion that the rate of protamine infusion is important implies a protamine-induced histamine release. Indeed, protamine is a basic drug that could release histamine and other vasoactive molecules from mast cells and basophils. Recently, the basic drugs d-tubocurarine and morphine have been reported to produce haemodynamic changes that parallel in- 
creases in the circulatory concentrations of histamine. ${ }^{7}$ Finally, others have proposed a direct negative inotropic effect of protamine. ${ }^{8}$

The present study was conducted in patients and dogs with the goal of detecting any species difference in the haemodynamic changes associated with the intravenous administration of protamine. In addition, the plasma concentrations of histamine were measured to define the possible role of this vasoactive substance when haemodynamic changes accompany infusion of protamine.

\section{Methods}

Patient studies

Six adult patients $(61 \pm 3$ years, $75 \pm 8 \mathrm{~kg}$, mean \pm SD) scheduled for elective aortocoronary bypass graft surgery were studied. The protocol was approved by the institutional Review Committee for the study of human subjects and informed consent was obtained. All patients were receiving propranolol preoperatively with the last dose administered with the preoperative medication on the moming of surgery. Preoperative medication was with intramuscular morphine and scopolamine and oral diazepam. Following placement of catheters in a peripheral vein and the radial artery, anaesthesia was induced with diazepam $0.5 \mathrm{mg} \cdot \mathrm{kg}^{-1}$ adminis tered intravenously over five minutes. Skeletal muscle paralysis was produced with metocurine $\left(0.15 \mathrm{mg} \cdot \mathrm{kg}^{-1}\right)$ plus pancuronium $\left(0.08 \mathrm{mg} \cdot \mathrm{kg}^{-1}\right)$. Following intubation of the trachea, a thermodilution pulmonary artery catheter was positioned in the pulmonary artery via the right intemal jugular vein. Maintenance of anaesthesia was with morphine 1.5 $m g \mathrm{~kg}^{-1}$ administered intravenously plus intermittent isoflurane to treat elevations in blood pressure more than 20 per cent above awake levels. All patients received methylprednisolone (1 gram) and cefamandole (1 to 2 grams) intravenously shortly after the induction of anaesthesia.

Cardiopulmonary bypass was initiated $55 \pm 15$ minutes after the induction of anaesthesia and lasted $114 \pm 26$ minutes. Hemodilution and hypothermia was utilized and the activated clotting time maintained at greater than 400 seconds with heparin. At the conclusion of cardiopulmonary bypass, the patient's intravascular fluid volume was adjusted by the infusion of pump perfusate via the aortic cannula. When systemic and pulmonary artery pressures were judged optimal and had been stable for at least three minutes, the aortic and venous cannulae were removed. Control haemodynamic measurements and arterial and venous blood for measurement of histamine concentrations, blood gases and $\mathrm{pH}$, and were obtained. Blood for plasma histamine measurements was drawn simultaneously from the radial artery and distal port of the pulmonary artery catheter and immediately placed in precooled test tubes containing EDTA. The plasma was separated within 30 minutes of collection using a centrifuge and the samples frozen for subsequent analysis.

The dose of protamine $(352 \pm 103 \mathrm{mg}, 4.7$ $\mathrm{mg} \cdot \mathrm{kg}^{-1}$ ) (Eli Lilly) was calculated from the activated clotting time titration curve for each patient and subsequently administered as a continuous intravenous infusion over five minutes via a peripheral forearm vein. All measurements were repeated at the conclusion of and five minutes after the protamine infusion. No anaesthetic or vasoactive drugs were being administered and surgical manipulation of the heart was deferred during the period of data collection.

Circulating histamine concentrations were determined using a new radioenzymatic assay. "10 10 The assay has a sensitivity of $2.2 \mathrm{pg} \cdot \mathrm{ml}^{-1}$ and a coefficient of variation of less than ten per cent. The sensitivity of the assay is due to the use of (1) a methyl donor ( ${ }^{3} \mathrm{H}-\mathrm{S}$-adenosylmethionine) with a specific activity of $76.1 \mathrm{Ci} / \mathrm{mmol}$; and (2) purificd histamine $\mathrm{N}$-methyltransferase. The enzyme is purified from rat kidney by centrifugation, pH 5.0 treatment, ammonium sulfate precipitation, ion exchange chromatography and molecular exclusion chromatography. ${ }^{9.10}$ Specificity of the assay was insured by performing the methyl transfer reaction at 0 to 4 Celsius. "

Standard formulae were used to calculate systemic vascular resistance, pulmonary vascular resistance and stroke volume. Data were analyzed using a two-way analysis of variance and Dunnet's test. A p value less than 0.05 was considered statistically significant.

\section{Dog studies}

Twelve mongrel dogs $(9 \pm 1 \mathrm{~kg})$ received intravenous thiopentone ( 10 to $15 \mathrm{mg} \cdot \mathrm{kg}^{-1}$ ) followed by intubation of the trachea. Maintenance of anaesthesia was with 1 to 1.5 per cent inspired halothane 
TABLE I Measurements (mean \pm SD) in patients receiving protamine over 5 minutes

\begin{tabular}{|c|c|c|c|}
\hline & Control & $\begin{array}{l}\text { End protamine } \\
\text { infusion }\end{array}$ & $\begin{array}{l}5 \text { minutes afier } \\
\text { protamine }\end{array}$ \\
\hline Systclic blaod pressure ( $\mathrm{mmH}$ ) & $120 \pm 15$ & $120 \pm 14$ & $120 \pm 16$ \\
\hline Diastolic blood pressure $(\mathrm{mm} H \mathrm{Hg})$ & $65 \pm 15$ & $65 \pm 13$ & $65 \pm 15$ \\
\hline Mean arterial pressure $(\mathrm{mmHg})$ & $86 \pm 15$ & $85 \pm 11$ & $87 \pm 17$ \\
\hline Heart ratc (bcats/min) & $77 \pm 15$ & $72 \pm 13$ & $71 \pm 10$ \\
\hline Systolic pulmonary artery pressure ( $\mathrm{mmHg}$ ) & $26 \pm 7$ & $25 \pm 7$ & $24 \pm 7$ \\
\hline Diastolic pulmonary artery pressure ( $\mathrm{mmHg}$ ) & $13 \pm 3$ & $11 \pm 3$ & $12 \pm 3$ \\
\hline Mean pulmonary artery pressure $(\mathrm{m} m \mathrm{mg})$ & $19 \div 5$ & $16 \div 4$ & $17 \pm 5$ \\
\hline Pulmonary artery occlusion pressure (muHg) & $12 \pm 2$ & $12 \pm 2$ & $11 \pm 3$ \\
\hline Mean right atrial pressure $(\mathrm{mmHg})$ & $9 \pm 3$ & $8 \pm 2$ & $7 \pm 3$ \\
\hline Cardiac output (1/min) & $5.8 \pm 1.1$ & $5.6 \pm 0.5$ & $5.4 \pm 0.6$ \\
\hline Stroke volume (ml/beat) & $78 \pm 16$ & $79 \pm 12$ & $78 \pm 17$ \\
\hline Systemic viscular resistance (units) & $14 \pm 3$ & $14 \pm 2$ & $15 \pm 4$ \\
\hline Pulmonary vascular resistance (units) & $1.2 \pm 0.6$ & $0.8 \pm 0.3$ & $1.1 \pm 0.4$ \\
\hline Ancrial histamine $\left(\mathrm{pg} \cdot \mathrm{ml}^{-1}\right)$ & $156 \pm 63$ & $242 \pm 317$ & $214 \pm 125$ \\
\hline Mixed venous histamine (pg'ml ') & $186 \pm 165$ & $445 \pm 616$ & $256 \pm 1,37$ \\
\hline $\mathrm{PaO}_{2}(\mathrm{mmHg})$ & $356 \pm 50$ & $362 \pm 54$ & $356 \pm 70$ \\
\hline $\mathrm{PuO}_{2}(\mathrm{mmHg})$ & $47 \pm 5$ & $46 \pm 9$ & $44 \pm 4$ \\
\hline $\mathrm{PaCO}_{2}$ & $35 \pm 3$ & $33 \pm 4$ & $33 \pm 3$ \\
\hline $\mathrm{pHa}$ & $7.44 \pm 0.004$ & $7.46 \pm 0.05$ & $7.48 \pm 0.05$ \\
\hline Haematocrit (per cent) & $31 \pm 1$ & & \\
\hline Oesophageal/Temperature (Celsius) & $34.9 \pm 0.5$ & & \\
\hline
\end{tabular}

plus 60 per cent nitrous oxide in oxygen. Ventilation of the lungs was adjusted to maintain the $\mathrm{PaCO}_{2}$ between 30 to $40 \mathrm{mmHg}$. Esophageal temperature was monitored and a heating pad utilized to maintain temperature between 36.5 and $37.5^{\circ} \mathrm{C}$. A catheter was placed in the femoral artery for continuous recording of blood pressure and calculation of heart rate. Propranolol $0.1 \mathrm{mg} \mathrm{kg}^{-1}$ was administered intravenously shortly after the induction of anaesthesia. Heparin was not administered to the dogs. After at least one hour of anaesthesia, control haemodynamic measurements (systolic, diastolic and mean arterial pressure and heart rate) and arterial blood for determination of histamine concentration and blood gases were obtained. Six dogs then received intravenous protamine $4.5 \mathrm{mg} \cdot \mathrm{kg}^{-1}$ administered over five minutes and six other dogs received the same dose of protamine as a rapid intravenous injection. Haemodynamic measurements and arterial blood for plasma histamine determinations were obtained at various times up to ten minutes after the injection of protamine. Blood samples for histamine determination were handled as described for the patients.

\section{Results}

The intravenous administration of protamine over five minutes to six patients did not produce hemodynamic changes (Table l). Likewise, circulating histamine concentrations did not change signi-

TABLE II Measurements (IItedn \pm SD) in dogss receiving protimige over 5 minutes

\begin{tabular}{|c|c|c|c|c|c|}
\hline & \multirow[b]{2}{*}{ Control } & \multicolumn{2}{|c|}{ Protanine infusion } & \multicolumn{2}{|c|}{ Afler prolamine } \\
\hline & & $2.5 \mathrm{~min}$ & $5 \mathrm{~min}$ & $5 \mathrm{~min}$ & $10 \mathrm{~min}$ \\
\hline Systolic blood pressure (mirnHg) & $105 \pm 9$ & $104 \pm 10$ & $95 \pm 15$ & $103 \pm 9$ & $104 \pm 9$ \\
\hline Diastolic blood pressure (mmHg) & $64 \pm 9$ & $64 \pm 9$ & $58 \pm 14$ & $61 \pm 7$ & $59 \pm 7$ \\
\hline Mean arterial pressure (mmHg) & $78 \pm 8$ & $77 \pm 8$ & $71 \pm 9$ & $74 \pm 9$ & $72 \pm 9$ \\
\hline Heart rate (beats/min) & $112 \pm 7$ & $111 \pm 7$ & $111 \pm 6$ & $113 \pm 10$ & $110 \pm 11$ \\
\hline Anterial histamine (pg $\cdot \mathrm{ml}^{-1}$ ) & $334 \pm 217$ & & $45.3 \pm 266$ & $445 \pm 194$ & $305 \pm 208$ \\
\hline Protamine (me) & $43 \pm 8$ & & & & \\
\hline
\end{tabular}


TABLE III Measurements (mean \pm SD) in dogs before and for 10 minutes after rapid injection of protamine

\begin{tabular}{|c|c|c|c|c|c|}
\hline & \multirow[b]{2}{*}{ Control } & \multicolumn{4}{|c|}{ Afrer protamine } \\
\hline & & Imin & $2.5 \mathrm{~min}$ & 5 min & 10 min \\
\hline Systolic blood pressure (mmHg) & $105=16$ & $102 \pm 18$ & $78 \pm 25^{*}$ & $95 \pm 9$ & $99 \pm 14$ \\
\hline Diastolic blood pressure $(\mathrm{mmHg})$ & $68 \pm 14$ & $65 \perp 16$ & $47 \perp 18^{t}$ & $59 \pm 7$ & $62 \pm 11$ \\
\hline Mean arterial pressure (mmig) & $80 \pm 13$ & $77 \pm 15$ & $58 \pm 20^{*}$ & $71 \pm 7$ & $74 \pm 12$ \\
\hline Heart rate (beats/min) & $107=16$ & $107=14$ & $99 \pm 22$ & $101 \pm 17$ & $104 \pm 14$ \\
\hline Arterial histamine $\left(\mathrm{pg} \cdot \mathrm{mi}^{-1}\right.$ & $291=71$ & $351=129$ & $860 \pm 465^{*}$ & $431 \pm 241$ & $315 \pm 69$ \\
\hline Protamine (mg) & $38 \pm 5$ & & & & \\
\hline
\end{tabular}

$* 0<0.05$.

ficantly $(\mathrm{p}>0.05)$ although there was a trend for levels to be increased at the conclusion of the protamine infusion. The mixed venous concentrations of histamine were greater than the arterial levels, but this difference was not significant $(p)$ 0.05 ).

Administration of protamine to doys produced hasmodynamic changes that were dependent on the rate of infusion. For example, administration of protamine over five minutes did not significantly ( $p$ $<0.05$ ) reduce blood pressure, alter heart rate or change the arterial concentration of histamine (Table 1I). Conversely, the rapid intravenous administration of protamine transiently lowered blood pressure in association with nearly a threefold increase in the arterial concentration of histamine (Table IlI, Figure).

\section{Discussion}

These data obtained in patients fail to demonstrate haemodynamic changes or alterations in circulating concentrations of histamine when protamine was administered over five minutes to reverse heparin anticoagulation at the conclusion of cardiopulmonary bypass. It is important to emphasize that all our patients were haemodynamically stable and were presumed to be normovolemic. A similar rate of administration of protamine to halothane-anaesthetized dogs, also, did not alter blood pressure, heart rate or the arterial concentration of histamine. Conversely, the same dose of protamine administered as a rapid intravenous injection to dogs produced transient reductions in systolic, diastolic and mean blood pressure $(p<0.05)$ that paralleled equally transient increases in the arterial concentrations of histamine ( $p<0.05$ ). It is well known that rapid injection of a basic drug and the resulting high plasma concentration is more likely than a slow infusion to provoke degranulation of mast cells and basophils manifesting as release of histamine. ${ }^{12}$

It has been postulated that the dog is more likely than man to experience protamine-induced hacmodynamic changes presumably due to histamine

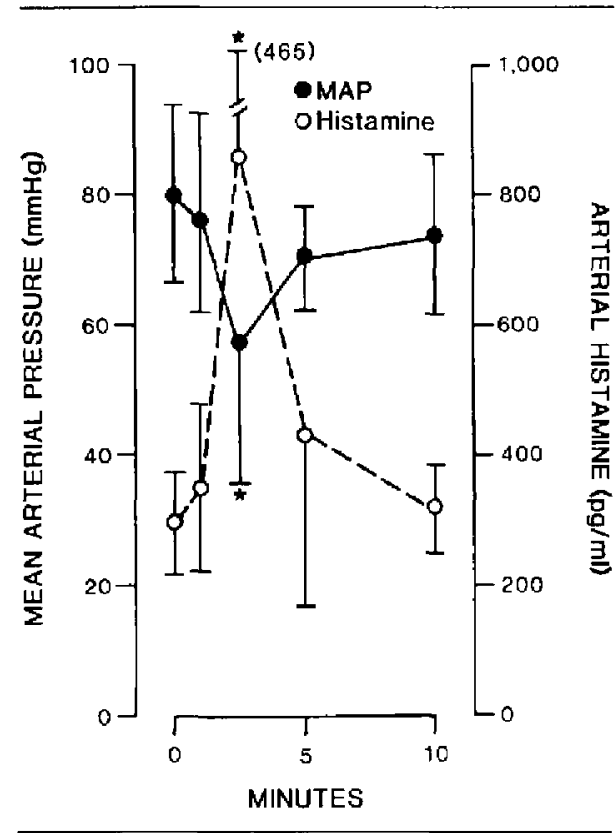

FIGURE The mean arerial pressure (solid circlesi (mean \pm SD) decreased ( $p<0.05) 2.5$ minutes following the rapid injection of protamine ( $\left.4.5 \mathrm{mg} \cdot \mathrm{kg}^{-1}\right)$ to six halothaneanesthetized dogs. This decrease in mean arterial pressure was accompanied by a corresponding increase $\left({ }^{*} \mathrm{p}<0.05\right)$ in the arterial concentration of histamine (open circles). 
release. $^{4}$ Our data do not directly support this speculation since administration of similar doses of protamine over five minutes to dogs and patients were not associated with significant changes in blood pressure. There was, however, a tendency for circulating histamine concentrations to increase during the five minutes of protamine infusion in both patients and dogs. Rapid intravenous injection of protamine to patients was not tested in this study so comparison of circulating histamine concentrations with dogs receiving protamine rapidly is not possible. Perhaps, rapid injection of protamine to patients would evoke histamine release to a similar extent as observed in dogs. Nevertheless, in another report, administration of protamine over 30 seconds or 60 seconds to patients at the conclusion of cardiopulmonary bypass produced only minor and transient decreases in blood pressure and systemic vascular resistance. ${ }^{6}$

Previous studies have suggested protamine may have direct cardiac depressant effects. ${ }^{3,8}$ In our patients, however, there was no evidence of cardiac depression as reflected by unchanged right atrial pressure, pulmonary artery occlusion pressure and cardiac output.

Protamine has been reported to result in pulmonary vascular vasoconstriction with corresponding increases in pulmonary vascular resistance. ${ }^{13}$ This observation, however, is not supported by data from our patients in whom pulmonary vascular pressures and calculated pulmonary vascular resistances did not change.

Heart rate did not change in response to protamine infusion. This contrasts with previous animal reports describing bradycarcia. ${ }^{2}$ Conversely, an increased heart rate in association with protamine infusion could reflect histamine-induced epinephrine release. ${ }^{14}$ We speculate that background betaadrenergic blockade in our patients and dogs contributed to the lack of change in heart rate. Alternatively, drugs used for anaesthesia (morphine, halothane) or intrinsic cardiac disease in patients may have blocked heart rate changes. Propranolol was utilized in our dogs to more closely mimic the clinical picture in which protamine is administered to patients. Previous animal data, however, have demonstrated that propranolol dues nol alter the haemodynamic effects evoked by protamine. ${ }^{3}$

We elected not to heparinize the dogs prior to administcring protamine. This decision was based on the assumption that interaction of protamine with heparin was in no way responsible for any haemodynamic effects. In retrospect, this may be questioned, as it has been suggested that the protanineheparin complex may be important for eliciting haemodynamic changes attributed to protamine. ${ }^{\text {is }}$ Nevertheless, the absence of haemodynamic changes in heparinized patients receiving protamine and the presence of blood pressure changes that paralleled increases in the circulating concentration of histamine when protamine was administered to unheparinized dogs fails to support the speculated haemodynamic importance of the protamineheparin complex.

Our patients all received methylprednisolone shortly after the induction of anaesthesia. Although the intervals varied somewhat, it was usually about three hours after methylprednisolone when protamine was administered. Conceivably, methylprednisolone which is alleged to prevent activation of complement in the lung could have attenuated the haemodynamic effects evoked by protamine ${ }^{6}$ Indeed, generation of complement-derived anaphylatoxins has been attributed to protamine as well as exposure of blood to components of the cardiopulmonary bypass machine. ${ }^{16}$ Similarly, methylprednisolone may have stabilized mast cell and basophil membranes and inhitibed release of histamine. This, however, is unlikely, since 12 to 24 hours is required for glucocorticoids to inhibit histamine release. ${ }^{17}$ Our desire not to alter the usual clinical management of our study patients was the reason for not studying a group not receiving methylprednisolone. Dogs: however, were not given methylprednisolone and the absence of haemodynamic changes in those animals receiving protamine over five minutes supports out hypothesis that the presence or absence of methylprednisolone does not influence the haemodynamic responses to protamine.

Morphine, as administered to our patients, is more likely than fentanyl to evoke a transient release of histamine. ${ }^{8}$ This raises a theoretical question of histamine depletion by morphine which might attenuate or prevent subsequent protamineinduced release of this vasoactive substance and associated circulatory effects. It is not possible to discount this possibility in our study, but the time interval between morphine administration and injection of protamine (at least threc hours) plus the 
unlikely ability of any drug to significantly deplete total body histamine stores leads us to conclude that morphine did not infuence our results via this theoretica! mechanism. Furthermore, none of our patients manifested circulatory changes during the initial administration of morphine that were associated with cutaneous flushing suggestive of histamine release.

In contrast to patients, maintenance of anaesthesia in the dogs did not include morphine. The decision to administer halothane to the dogs was based on our desire to produce a stable depth of anaesthesia so as to minimize the potential impact of a changing or inadequate depth of anaesthesia on the magnitude of protamine-induced circulatory changes. We felt this goal was more likely to be attained with a volatile anaesthetic rather than a narcotic.

Measurement of arterial and mixed venous concentrations of histamine revealed a consistent, although not statistically significant, difference with the venous concentration being greater than the arterial. This observation suggests histamine may be removed from the circulation as it traverses the lungs. Furthermore, a higher mixed venous concentration of histamine supports release of this vasoactive substance from splanchnic tissues and the skin. Conversely, others have demonstrated protamine-induced circulatory effects in patients when protamine was injected directly into the aorta but not intravenously. ${ }^{18}$

In summary, our data demonstrate that administration of protamine over five minutes to patients following cardiopulmonary bypass does not evoke haemodynamic changes or physiologically important alterations in the circulating concentrations of histamine. Likewise, protamine administered over five minutes to dogs was haemodynamically benign. Conversely, rapid injection of protamine to dogs caused transient decreases in blood pressure that paralleled equally transient increases in the arterial concentrations of histamine (Table IIl, Figure).

\section{References}

1 Hurt $R$, Perkins HA, Osborn JJ, Gerboule $F$. The neutralization of heparin by protamine in extracorpo real circulation. J Thorac Surg 1956; 32: 612-9

2 Gourin $A$, Streisand $R L$, Greineder $J K$, Stuckey $J H$ Protamine sulfate administration and the cardio- vascular system. J Thorac Cardiovasc Surg 1971;62: 193-204.

3 Fadali MA, Papacosias CA, Duke JJ, Ledbener M, Oskakken $M$. Cardiovascular depressant elfect of protamine sulphate: experimental study and clinical implications. Thorax 1976; 31: 320-3.

4 Conahan TJ, Andrews RW, Macvaugh H. Cardiovascular effects of protamine sulfate in man. Anesth Analg 1981; 60: 33-6.

5 Sethna DH, Moffit E. Gray RJ, et al. Effects of protamine sulfate on myocardial oxygen supply and demand in patients following cardiopulmonary bypass. Anesth Analg 1982; 61: 247-51.

6 Shapira N, Schalf HV. Piehter IM, White RD, sill $J C$, Pluth $J R$. Cardiovascular effects of protanine sulfate in man. J Thorac Cardiovasc Surg 1982; 84: 505-14.

7 Roscow CE, Moss J, Philbin DM, Satarese JJ. Histamine release during morphine and fentanyl anaesthesia. Anesthesiology 1982; 56: 93-6.

8 Iwatsuki N, Matsukawa S, Matstki K. A weak negative inotropic effect of protamine sulfatc upon the isolated canine heart muscle. Anesth Analg 1980; 59: 100-2.

9 Verburg KM, Bowsher RR, Henry DP. A new radioenzymatic assay for histamine using purified histamine $\mathrm{N}$-methyltransferase. Life Sci 1983, 32 : 2855-67.

10 Bowsher RR, Verburg KM, Henry DP. Histamine $\mathrm{N}$-methyltransferase: quantification, tissue distribution, purification, and immunologic propertics. J $B$ iol Chem (in press).

11 Verburg $K M$, Bowsher RR, Hemry DP. Kinctic analysis of histamine $\mathrm{N}$-methyltransferase: effect on the histamine radioenzymatic assay. Fed Proc 1983: 42: 907 .

12 Beaven MA. Anaphylactoid reactions to ancsthetic drugs. Anesthesiology 1981; 55: 3-5.

13 Lowenstein E, Johnston WE, Lappas DG, el al. Catastrophic pulmonary vasoconstriction associated with protamine reversal of heparin. Anesthcsiology 1983; 59: 470-3.

14 Moss J, Fahmy NR, Sunder N. Beaven MA. Hormonal and hemodynamie profile of an anaphylactic reaction in man. Circulation 1981; 63:210-3.

15 Egertson WS, Robinson CLN. The anti-heparin, anticoagulant and hypotensive properties of hexadimethrine and protamine. Lancet $1961 ; 2: 635-7$.

16 Chenoweth $D E$, Cooper SW, Hught TE, Stewart $R W$ Blackstone EH, Kirklin JW. Complement activation 
during cardiopulmonary bypass: evidence for generation of $\mathrm{C} 3 \mathrm{a}$ and $\mathrm{CS}$ a anaphylatoxins. $\mathrm{N}$ Engl J Med 1981; 304: 497-503.

17 Schleimer RP, Lichenstein LM, Gillespie E. Inhibition of basophil histamine release by antjinflammatory steroids. Nature 1981; 292: 454-5.

18 Milue B, Rogers K, Cervenko F, Salerno T. The haemodynamic effects of intraaortic versus intravenous administration of protamine for reversal of heparin in man. Can Anaesth Soc J 1983; 30: $347-5$ l.

\section{Résumé}

On a mesuré les répercussions sur l'hêmodynamique el les concentrations plasmatiques d'histamine occasionnées par l' inflasion de protamine chez six parients aduites opérés pour pontage auro-coronarien et che: douze chiens anesthésiés à l'halothane.

Chez les parients à l'arrêt de la circulation extreicorporelle, l'infusion de protanine $\left(4.7 \mathrm{mg} \cdot \mathrm{kg}^{-1}\right)$ n'a pu aucun effet sur l'hémodynamique ou les concentration. artérieiles et veineuses distamine. De la nếne façon, I"infusion d' une dose de $4.5 \mathrm{mg} \cdot \mathrm{kg}^{-i}$ de protamine sur une période de cinq minutes chez six chiens n'a eu ancun effer. Cependant lorsque la dose a été administrée en injection intraveineuse rapide à six autres chiens, on a observé une réduction de l'ordre de 30 pour cent de la pression arrérielle systolique et diastolique et moyeme ( $p$ $<0.0512 .5$ minutes après l'injection. Ces modifications de pression artérielle s'accompagnaient de fayon parallele ditue augmenation de la conceniration ariérielle d' histamine, concentration qui passair de $295 \pm 71 \mathrm{pg} \cdot \mathrm{ml}^{\prime}$ $(M \pm D S)$ a $860 \pm 465 \mathrm{pg} \cdot \mathrm{ml}^{-1}(p<0.05) 2.5$ minutes après l'injecrion. Ces mesures d'hémodynamie et d'his. tamine avaient retrowé les vileurs de coutrôle cinq minutes après l'administration de protamine.

On en conclut que linjection de protamine sur un périade de cinq minutes aux patients comme aux chliens ne suscite pas de modificntions hémodynamizures notables ou de changements de concentration de l'histamine plasmatique. Cependant, l' injection rapide de protamine chez des chiens provoque ume diminution fugace de la pression artérielle, diminution qui s'accompagne de concentration à la hausse thistamine dans le sang artériel. 